ISSN 2236-0859

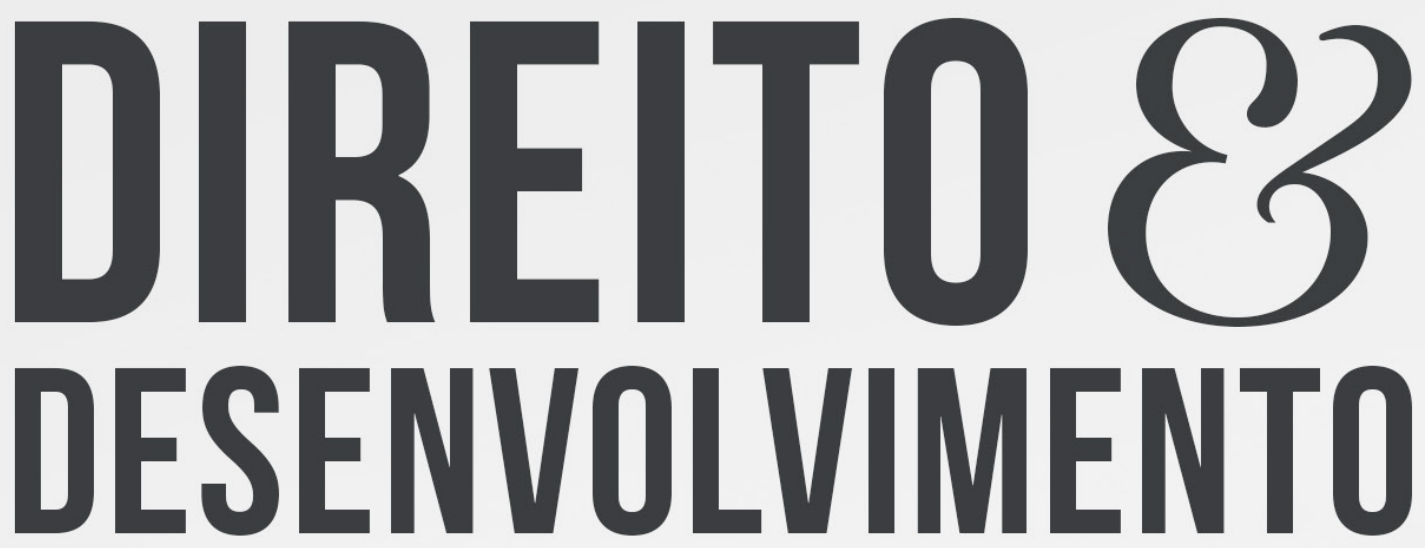

REVISTA DO PROGRAMA DE PÓS-GRADUAÇÃO EM DIREITO MESTRADO EM DIREITO E DESENVOLVIMENTO SUSTENTÁVEL

PENITENTIARY AND CRIMINAL INCLUSIVE PUBLIC POLICY OF DISCHARGE FOR THE READING OF LITERATURE CLASSICS

THAIIS LINO DOS SANTOS

ANDRÉ RICARDO FONSÊCA DA SILVA 


\title{
PENITENTIARY AND CRIMINAL INCLUSIVE PUBLIC POLICY OF DISCHARGE FOR THE READING OF LITERATURE CLASSICS
}

\author{
POLÍTICA PÚBLICA PENITENCIÁRIA E CRIMINAL INCLUSIVA \\ DE REMIÇÃO PELA LEITURA DE CLÁSSICOS DA LITERATURA
}

Recebido: 30/05/2019

Aprovado: 30/05/2019

Thaís Lino dos Santos ${ }^{1}$

André Ricardo Fonsêca da Silva ${ }^{2}$

\section{SUMMARY}

This article deals with a study about the efficacy of reading literature classics as a complementary educational activity in the discharge process. It is an attempt to construct public policies aimed at the re-education of the distressed student, escaping from the social imaginary dominated by punitive and repressive thinking regarding crime and violence. The practice of reading in criminal facilities deserves greater diffusion and application in the process of remission of the sentence, since it presents the maximum plausibility for an effective reeducation of the prisoner and its consequent social inclusion. We live in a world with a view to sustainability, where peace, justice, freedom, dignity, fraternity are in the process of achieving its highest level of effectiveness. It is no longer possible to perpetuate a criminal policy that has long demonstrated its inefficiency. It is through the practice of reading in criminal facilities, more specifically the reading of classics of the universal and Brazilian literature, that it is intended to defend a humanizing public policy, in opposition to the merely criminal policies that are still applied in the XXI century. The methodology used was qualitative, using the method of historical-comparative-sociological procedure and bibliographic research.

Keywords: Public Policies. Remission by Reading. Classics of Literature.

\section{RESUMO}

Este artigo trata de um estudo sobre a eficácia da leitura de clássicos da literatura como atividade educacional complementar no processo de remição da pena. Trata-se de uma tentativa de construção de políticas públicas voltadas para a reeducação do apenado-educando, fugindo do imaginário social dominado por um pensamento punitivo e repressivo no tocante a criminalidade e violência. A prática da leitura em estabelecimentos penais merece maior difusão e aplicação no processo de remição da pena, uma vez que se apresenta de máxima plausibilidade para uma efetiva reeducação do preso e sua consequente inclusão social. Vive-se em um mundo com vistas

1 Doctorate in Sciences from the Pontifical University of Buenos Aires (UCA). MSc in Law and Sociopolitical Development (UNIPE). Specialist in Civil Procedure Law (CERS - Estácio de Sá). Specialist in Criminal, Criminal Procedure and Criminal Expertise (FESMIP-PB). Graduated in Law from the University Center of João Pessoa (UNIPE). Judicial Practice with Judicial Residence by the Superior School of Magistracy (ESMA). Conciliador and Mediator by the National Council of Justice (CNJ). Email: thaislinobusiness@gmail.com

${ }^{2} \mathrm{PhD}$ in Public Policies and Human Education (UERJ). Master in Legal Sciences (UFPB). Specialist in Municipal Law (UNIPE). Graduated in Law (UNIPE). Coordinator of the On-Theology Course at the Faculdade Internacional Cidade Viva-FICV. Permanent Professor of the Master in Law of UNIPE. Adjunct Professor of UNIPE Graduation. Editor-in-Chief of the Scientific Journal: Law and Development of PPGD / UNIPE (ISSN 2236-0859). Email: professor.andrefonseca@gmail.com 
à sustentabilidade, onde a paz, justiça, liberdade, dignidade, fraternidade se encontram em vias de seu mais elevado nível de efetivação. Não é mais possível se perpetuar uma política criminal que já demonstra há tempos sua ineficiência. É pela prática da leitura nos estabelecimentos penais, mais especificamente da leitura de clássicos da literatura universal e brasileira, que se pretende defender uma política pública humanizadora, em oposição às políticas meramente criminais que se costumam ainda aplicar em pleno século XXI. A metodologia empregada foi a qualitativa, com o uso do método de procedimento histórico-comparativo-sociológico e pesquisa bibliográfica.

Palavras-chave: Políticas Públicas. Remição pela Leitura. Clássicos da Literatura.

\section{INTRODUCTION}

The social crisis experienced today in Brazil, of which crime and violence are inseparable, is also due to the crisis of the repressive model applied in criminal and penitentiary public policies today. It is a repressive policy that had never been abandoned by the criminal-legal ideals. The problem of Brazilian crime and violence is of a social nature and is far from being solved only with measures of a repressive character. This logic has long demonstrated that it is not capable of solving social problems, but only aggravates them. It is not without reason that Mauro Malin (2018) asserts that the abuse of repression is undemocratic, weakens authority and fuels corruption.

This is the thinking contained in this study: criminal and penitentiary public policies still need to be more distanced from the ideas propagated by the Criminal Law of the Enemy, who only sees the individual as the center that causes all the evils of society. The State must assume its social responsibility in the face of the criminality and violence that afflicts Brazil and, above all, in relation to the process of resocialization of the prisoner, subject discussed here.

In the process of resocialization of the prisoner, there are measures such as remission, species of release of sentence through the practice of various activities that inmates can perform. Among the possibilities of remission, we have the educational activities, direction to where this study intends to guide. It is within these educational activities, more specifically those of a complementary nature, using a term used by DEPEN - National Penitentiary Department -, that this proposal of incentive to practice reading in criminal facilities is inserted.

It is, more specifically, the incentive to read classics of the literature as a form of remission and resocialization, therefore, to be included in the plans for the execution of public criminal and penitentiary policies. These are still deeply rooted in punitive thinking, when they should encompass the social aspect of the activities selected for the prisoners. The reading of classics in literature is thus one of the most effective ways of remission and consequent re-socialization of prisoners precisely because of their transforming character of the human person. It is absent or little used by Brazilian penitentiaries and it is hoped that its diffusion will be ample due to the excellent results obtained with this activity, already verified in few Brazilian states.

It aims to clarify a critical reflection on the problems of resocialization, which are loaded with a defective ideology because it has a strictly punitive character. The diffusion of the complementary educational activity of reading classics from the literature in our criminal facilities expands the horizons about remissions endowed with a social aspect, humanizing, citizen. To do so, the bases of Brazilian public criminal and penitentiary policies would need 
adjustments in their foundations; adjustments that were based on the idea of sustainability, with proposals aimed at the re-education of more just and peaceful societies.

The methodology applied in this study followed the qualitative approach, evaluating aspects related to the quality of life of the prisoners and their living conditions in penitentiaries, in search of proposals that aim at a characterization of public criminal and penitentiary policies as socializers, humanizing. Using the method of historical-comparative-sociological procedure, it was possible to establish analogies between punitive and citizen policies, considering the need to update these public policies to the new sustainable reality in which we live, as well as trying to systematize the positive impacts that the reading can provoke in the process of constructing a citizen conscience among the grieving ones. The theoretical research was also evident at all times, with the use of bibliographical studies, with the use of analytical and reference works.

Structurally, this article is organized in four chapters, in addition to our introduction and final considerations: the first presents reports on Brazilian thinking about crime; the second expresses the Brazilian penitentiary system as a deposit of human people deprived of dignified conditions for the fulfillment of the sentence; the third discusses the inclusive aspect of the Criminal Enforcement Act; and the fourth, defends the presence of the inclusive aspect as the basic principle of our criminal and penitentiary public policies.

\section{BRAZILIAN SOCIAL IMAGINARY}

It is important to start working on this level by saying that there are two world views about what is being discussed here. This is necessary because it is a prior knowledge that will be fundamental for the positioning of the person in front of the facts narrated throughout the text.

The first view is that which attributes to the individual all the notion of culpability for the criminal act practiced - this is true, because of the defendant's autonomy of will; if he did not have this autonomy of will, there would be no sense in any criminal responsibility. In this conception, the being is blamed for its mistakes and must pay severely for what it has done. The population comes together to collect a set of severe measures against this criminal. This is a very common view of positivist criminologists in the early twentieth century.

The second view is that the criminal action is meant to be the reason for the person who practiced it to be punished with dignity, because it is also endowed with human rights like any other. To the State is attributed responsibility for the acts of this citizen, since it has not fulfilled its social function, namely: to provide conditions of citizenship and dignity to the people, so that they live in a prosperous way at work and with their family. The adherents of this line are the indoctrinators Guilherme Nucci, André Ramos Tavares, Raul Zaffaroni etc.

These two notions are necessary because they will influence the social imaginary, a determinant factor for the referral of criminal and penitentiary public policies adapted or not to the social. This is explained by knowing that rulers will only remain in power if they have the support of the people. Being the mass against the people who commit the crime, feeding a feeling of revenge before this group of criminals, it will be difficult to have public policies that promote the social inclusion of these people, since being to provide the reeducation of this class would be the same as being on their side; and it would be the same as not to perpetuate itself in power. Thus, public policies of re-socialization of the criminal person will not be encouraged (SPOSATO, MARQUES, 2012). 
However, if the masses had a more human thought in view of their conception of the other, we would have a more citizenly and responsible view of the one who practices the crime. This would mean that our leaders could act more forcefully and effectively on criminal and penitentiary policies. This is because there would be no concern to know if one would lose votes because of the implementation of affirmative actions in favor of the penitentiary community. Possibly there would be more policies aimed at what we intend to defend here in this research: the promotion of reading as a complementary educational activity necessary for the social inclusion of the prisoner (SPOSATO, MARQUES, 2012).

\section{BRAZILIAN PENITENTIARY SYSTEM AS A DEPOSIT}

All this panorama of the punitive, individualistic and consumerist social imaginary built in Brazil by the masses and the media, and represented by our rulers, tends to favor, in principle, an institutional chaos installed in criminal facilities. Overcrowding in criminal facilities is one of the serious problems facing the Brazilian penitentiary system:

Brazil's prison population has grown 83 times in seventy years. This is what a mapping conducted by the Brazilian Public Security Forum with the support of Ipea showed, based on data published in the Statistical Yearbook of the Brazilian Institute of Geography and Statistics (IBGE). The total number of prisoners convicted in the prison system increased from 3,866 people in 1938 to 321,014 in 2009 (figure 1). If we consider more recent information, and $38 \%$ of the prison population is in a provisional situation, the reality is even more dramatic: Brazil had, in 2012, 515,482 people imprisoned for only 303,741 vacancies, a deficit of 211,741 vacancies. Brazil is already the fourth country that has most imprisoned in the world 4 , and yet it lives with very high crime rates, according to the Brazilian Yearbook of Public Security (2012). The alarming data point to the need for in-depth studies on the role or non-re-socialization of prisons, the phenomenon of criminal recidivism and its determinants, as well as on the effectiveness of alternative devices as a means of getting around this crisis in the prison system Brazilian (CNJ, 2015, p.10).

The overcrowding of prisons is one of the main problems faced by Directors of criminal facilities. Several rebellions have already occurred because of this. For example, the "Urso Branco" Prison is known for a daily history marked by executions, torture and ill-treatment of prisoners due to overcrowding. In 2007, the Justice and Peace Commission of the Archdiocese of Porto Velho and Global Justice had sent a report alerting the members of the Inter-American Court of Human Rights to the chaotic situation of the site. The disregard of the Brazilian authorities responsible for the prison and the failure to comply with the IACHR guidelines on the case culminated in one of the greatest rebellions ever to occur in Brazil, with worldwide repercussions. Newspapers from Rondonia reported that a mutiny had occurred on the first day of 2012: prisoners from some of the pavilions began murdering inmates of the so-called "Seguro", where those who were threatened with death were living. Scenes of horror were recorded: 27 prisoners were killed by blows (handguns) and had severed heads and other parts of the body $(\mathrm{G} 1,2019)$.

Public policies are limited to punishment and repression, with the aim of placing more and more people in prison. A clear example of this scenario is the current draft law of the Minister Sérgio Moro, who is only concerned with expanding the possibilities of inserting more people in penitentiaries, when he should be concerned about how to promote criminal and penitentiary public policies of social reintegration of or even to solve the problem of 
overcrowding in criminal facilities - this is much more difficult in the short term because it involves the collaboration of integrated public social policies.

Consequently, crowded penitentiaries, as evidenced by data from the Department of Penitentiary Institutions - DEPEN (CNJ, 2015), suggest that it is, in principle, a mere inability of managers to carry out a resocialization work to their satisfaction. This does not to exist the figure of a distressed-reeducating, since even the legal footage for the cell is respected. The most appropriate term for what should be a distressed-educated is, under current conditions, that of incarcerated. This is because people involved with crime are being treated as objects that are deposited in a cell; treated as animals, having to learn, there, that the world of crime is not worth it. This is when they do not reach the conclusion that it is better to get out of there as quickly as possible, taking advantage of leaks, for example, to return to doing with society the same thing that the penitentiary system does with them: torturing, humiliating, killing etc.

The violation of human rights is clear. This raises the problem of non-social reintegration of these individuals. It is impossible for one to be treated with degrading conditions and to express a return of affectionate, generous, charitable, respectful towards the other in society. The human being expresses what he had during his training. If at the time of his formation he lived in conditions of life scanty with dignity, work, love, nothing more plausible than expressing feelings of violence, repudiation, aversion and denial before society. And this in speaking of years of treatment that does not make it possible to exercise citizenship, in fact, does not allow the slightest notion of what this represents.

If there is no resocialization in penitentiaries there is also recurrence. Both are closely linked. Data from DEPEN (CNJ, 2015) show that the rate of recidivism in Brazil reaches $70 \%$. It is a clear demonstration that criminal and penitentiary policies need to be reviewed urgently:

This serious problem has led the public power and society to reflect on the current policy of criminal execution, giving rise to recognition of the need to rethink this policy, which, in practice, favors massive incarceration, the construction of new prisons and the creation of vacancies in detriment of other policies (CNJ, 2015, p.12).

The Brazilian Criminal Enforcement Law itself already shows a prominence for social inclusion in the criminal sphere.

\section{THE BRAZILIAN CRIMINAL EXECUTION LAW AND SOCIAL INCLUSION}

Law no. 7.210, dated July 11, 1984, known as the Criminal Execution Law (LEP), provides for the enforcement of "... the provisions of a sentence or a criminal decision ..." and determines " conditions for the harmonious social integration of the condemned and the interned, "according to its art. 10. In art. 3., the same law provides that "all rights not covered by the sentence or by law shall be guaranteed to the convicted person and the internee." It is right assured to the distressed-re-educating social inclusion.

Public criminal and penitentiary policies should include the provision of promotion of resocialization of distressed persons. It is known, however, that elaborating Public Policy to remedy Brazilian criminal problems is a task that may not give prestige to the rulers and bring down the media audience, as already mentioned in the first topic of this study. The National Plan for Criminal and Penitentiary Policies - PNPCP - begins its discussions about Brazilian crime, presenting this marked obstacle in our reality: 
Public policies demand governmental leadership in all instances, but in the case of criminal and penitentiary politics, it seems that governments are not confident that they can drive significant change and manage successfully. This unbelief, coupled with legislative opportunism and the profitability of the media, fuel a pernicious fatalism and a sense of revenge on the Brazilian people. The hatred of Brazilians against Brazilians is growing, institutional violence and extrajudicial "justice" is strengthened, stereotypes are instituted and institutions and costs of control are expanded (PNPCP, 2011, p.1).

Our population, lacking educational assistance, is full of stereotypes about prisoners, as discussed in the first topic of this paper. The media is also a great ally in the solidification and reduplication of this ideology, as was also seen at the beginning of our writings. Sposato and Marques (2012) explain that the ideological system of the current Brazilian punitive system is greatly reinforced by the publication of superficial and tendentious news by the media, functioning as a true police agency, that is, with the ability to misconfigure or configure the criminal act, according to with their political-economic interests.

Little is known about the rights of prisoners and many repudiate, at random or with common-sense arguments, Human Rights. To say that good bandit is dead bandit is one of the thoughts that spreads between society. However, it must be understood that an inmate is a human being endowed with equal dignity to any other person and therefore has his rights and duties similar to any citizen (UN, 2019): the criminal system selects people and not actions, turning their power to socially unfavorable classes, creating stereotypes and marginalizing those excluded from the process of capital accumulation, represented by the black, poor, unemployed and illiterate. This clientele is still the victim of the so-called suspicious attitude, consubstantiated in their class origin, extirpated from social and consumerist living (SPOSATO, MARQUES, 2019).

One can not forget that art. 50 of the CF does not allow the death penalty (except in case of declared war), much less torture, life imprisonment, forced labor, banishment or cruel. For this reason, and especially for principles that preserve the dignity of the human person and which propagate respect for the citizenship of all, it is not possible to assume a prejudiced stance towards the prison population (SPOSADO, MARQUES, 2012).

It has been clairvoyant the withdrawal of the condition of citizen of the human person, as well as the guarantees established by the legal order. This characteristic also runs counter to the resocializing policies of Brazil.

In order to comply with the Social Inclusion Provision of the Criminal Enforcement Act (LEP), resocializing public criminal and penitentiary policies must apply an equally inclusive working methodology. The argumentative rationalism devised by Perelman and OlbrechtsTyteca (1996) can not only be in theory, must overflow and reach organizational practices. Alongside public policies, a systematic implementation of activities should be organized, including monitoring, monitoring and evaluation of the practices being carried out.

Otherwise, there will be a developed theoretical entanglement that coexists with upto-date policies and practices that reflect the primacy of Descartes' Cartesianism. For this reason, the insertion of reading as an instrument of remission takes precisely the characteristic of denial of a simplistic ideology of punitivity. For this reason, Souza (2019), in commenting on this ideological systematics of the Criminal Law of the Enemy, states that it is absurd to consider the possibility of instituting a Criminal Law of the Enemy at the dawn of the twentyfirst century. It simply disrespects constitutional legality; is to go over all legal system and more, is to try to remove from the human being his condition of person and his dignity. Which is indeed impossible. 
This current thinking is one of the great obstacles that surround the process of elaboration of Public Policies directed at the Brazilian penitentiary system. It is not without reason that our criminal policy plan dates from 2011 and until today has not undergone the necessary updates to accompany a society in radical changes like the one that presents / displays today. The configuration of the present world lacks thinking beings, endowed with multiple skills and competences, and technology goers.

This is necessary in order to achieve, in fact, the constitution of a sustainable society. Since the year 200o, we have sought to achieve a society without the indignity of poverty, with the elaboration of the Millennium Development Goals by the United Nations - UN. With the failure to achieve these goals, another project to tackle the world's most urgent environmental, political and economic challenges is underway: the Sustainable Development Goals (SDG), number 17 (SACHS, 2017).

SDGs brought an important goal to the legal seventeenth century on peace, justice and effective institutions - promoting peaceful and inclusive societies for sustainable development, providing access to justice for all, and building effective, accountable and inclusive institutions at all levels (SACHS, 2017).

As they were also not fully achieved, the current UN Agenda 2030 was created, with 169 goals added to the 17 SDG. It arises with the objective of:

[...] to end poverty and hunger everywhere; combat inequalities within and between countries; building peaceful, just and inclusive societies; protect human rights and promote gender equality and the empowerment of women and girls; and ensure the lasting protection of the planet and its natural resources. We also resolve to create conditions for sustainable, inclusive and economically sustainable growth, shared prosperity and decent work for all, taking into account the different levels of development and national capacities (SACHS, 2017, p.67).

It is a very ambitious and transformative proposal which hopes to achieve, among other things, a world free from poverty, hunger, disease and poverty, where all life can prosper; a world free from fear and violence and all the evils that present society is experiencing. (ROCHA, 2014).

Only with inclusive public policies will it reach this level of sustainability that is indispensable for life in society.

\section{IN DEFENSE OF INCLUSIVE PUBLIC POLICIES}

The public policies focused on the criminal area must follow these new directions in the world, always in search of proposals that actually achieve, among other things, the reeducation of the human person from the distressed:

It is believed in a criminal policy proposal that defends citizenship and accountability. The purpose of this article is to present a proposal that approximates the current one that it considers important to reduce incarceration rates, to decriminalize conduct, to have different models of prisons for each segment, to combat criminal selectivity, to seek less criminal justice and more social justice, investing in restorative justice, empowering the population to seek a solution to conflicts, prioritizing alternative penalties for imprisonment, electing the prison system as a central problem, strengthening the state in the management of the criminal justice system, tackling all levels of corruption, tackling the issue of drugs in its multiple dimensions (social, economic, health, 
criminal), strengthen social control over the criminal system and have policy, method and specific management for the prison system (SPOSATO, MARQUES, 2012, page 28).

From a distance is shown a vision for:

[...] support penal hardening, increase incarceration rates, adopt the super-convictions model, ignore criminal selectivity, idolize custodial sentences, elect criminal factions as a central problem, support privatization of the criminal justice system, combat just the corruption of the tip, to judicialize all the behaviors of life, to potentiate the myth of drugs, to weaken and to criminalize the social movements and defenders of Human Rights and to consider the adjacent and consequent prison system of the police (PNPCP, 2019, 2).

Although the PNPCP represents a step forward in criminal and penitentiary policies, there is indeed an urgent need to adapt to all these ideas regarding the new social order today. The issue of resocialization is hardly addressed, although progress has already been made in guiding the construction of a vision of criminal justice and social justice.

In the LEP, it is observed that it allocates Chapter II only to deal with the assistance to the prisoner and the boarding school. Thus, it is stipulated that the purpose of this assistance is "(...) to prevent crime and guide the return to coexistence in society." The sole paragraph of this art. 10 still extends this right to egress. Among the forms of realization of this assistance, we have the educational modality, foreseen in art. 11, subsection IV.

In his art. 41, the legislature establishes that the inmate's right, item VI, is "the exercise of previous professional, intellectual, artistic and sporting activities, provided that they are compatible with the execution of the sentence". In addition, in section VII, of the same article, it is understood that the prisoner's right to "material, health, legal, educational, social and religious assistance".

The art. 82, of the LEP, also stipulates that criminal facilities must "(...) rely on areas and services designed to provide assistance, education, work, recreation and sports practice" to convicted persons, those subjected to security measures, interim prisoners and ex-offenders. Just as there are classrooms for primary and vocational courses, there could also be judicial reading rooms that would also support these courses.

In the LEP, therefore, the legislator provides all possibilities for the social inclusion of the prisoner. In fact, Law no. 12.714, dated September 14, 2012, which orders the system for monitoring the execution of sentences, the precautionary prison and the security measure, in its art. 1, ensures that "the data and information on the execution of the sentence, the precautionary prison and the security measure shall be maintained and updated in a computerized system to monitor the execution of the sentence." Among these data, the days of work or study must be recorded, as provided in art. 2, in its letter VI. In this sense, the days dedicated to the reading serve to be computed in the calculations of remission of the sentence.

However, resocialization practices that involve complementary educational activities such as reading are scarce in Brazil.

\subsection{REMARK BY READING}

In consultation with the National Prison Monitoring Bank of the CNJ, no evidence was found regarding those involved in educational activities. Probably indicating the absence or precariousness of libraries in criminal facilities. Analyzing the National Data of Penitentiary Information, published by DEPEN and elaborated by the Penitentiary Information Office 
(INFOPEN), one observes, regarding the criterion of prisoners involved in complementary educational activities (people enrolled in study, sports and other complementary educational activities - such as video library, leisure activities and culture), that "(...) only $12 \%$ of the prison population in Brazil is involved in some kind of educational activity, among those of school education and complementary activities ":

\begin{abstract}
Of particular note are the states of Bahia, Espírito Santo and Tocantins, which have the highest percentages of people involved in educational activities, above the national average. In relation to complementary activities, $2 \%$ of the country's total prison population is involved in reading or sports referral activities and other complementary educational activities. The state of Tocantins stands out for the greater percentage of people involved in this type of activity (INFOPEN, 2016, page 53).
\end{abstract}

Considering the distribution of persons deprived of their liberty according to the type of complementary educational activity by the Federation Unit, it is noted that "(...) among persons who are involved in complementary activities in the prison system, $43 \%$ are in referral programs through reading and another $1 \%$ are in referral programs through sports "(INFOPEN, 2016, p.55).

INFOPEN data are worrisome when analyzing the percentages of complementary educational activities aimed at the victims. The benefits of sport, culture and reading are innumerable and immeasurable. In our Magna Carta, including, as a function of the State, these activities are promoted for society (FUDOLI, 2004).

This is a worrying reality when one thinks of the numerous benefits that the reading, object of this study, can give to the formation of the citizen-distressed. States of the Federation that do not adopt or use little the program of remission for reading should follow the example of the State of Tocantins. And even in Tocantins, the rates are still very low. It would be incumbent upon the National Council of Criminal and Penitentiary Policy (NCCPP), as an organ of criminal execution, to strengthen in its PNPCP proposals that value, among other possibilities of remission, the practice of reading in penitentiary establishments, especially if this reading were classical works of universal and Brazilian literature.

The National Penitentiary Department, as an executive body of the National Penitentiary Policy and administrative and financial support of the National Council of Criminal and Penitentiary Policy (NCCPP), in partnership with the local Penitentiary Department, would have a primary role in this process. This would be possible due to its specific attributions of, according to art. 71 of the LEP:

I - to monitor the faithful application of the norms of penal execution throughout the national territory; II - periodically inspect and supervise criminal establishments and services; III - assist technically the federative units in the implementation of the principles and rules established in this Law [LEP]; IV - to collaborate with the federative units, through agreements, in the establishment of establishments and criminal services (BRASIL, 2019).

The collaboration of the management and the staff of the penal establishment, acting jointly with the Council of the Community, would be equally effective in proposing to implement the reading of classics in literature. This is because they are directly involved with the prison community and are knowledgeable about the importance of reading for the citizen training of the people and, therefore, on the process of re-socializing the prisoners. 


\subsection{READING OF LITERATURE CLASSICS}

We defend here the remission by reading classics from literature because they make it possible to analyze customs and situations in the most varied societies, in different times and in different places. Comparing with the reality in which they themselves were involved and are in the present, it is possible to reflect on their past, their present and future. This makes it self-critical in relation to its posture in certain moments, as of the people, and in the face of specific situations, enabling the formation of a citizen with a more critical and participatory awareness about his / her human condition vis-a-vis society. It is a study of human actions in different times, spaces and social groups, aiming at the improvement of citizen relations in society (CALVINO, 2007).

A sequential reading of classical works makes possible the understanding of conflictgenerating themes in our society. The reading of classics in literature is capable of presenting, for example, a historical chronology of the evolution of our society, a characteristic that is fundamental to understand also the social, historical, philosophical, cultural and educational changes throughout the ages. It is a study not only literary and hermeneutic, but also philosophical, anthropological, sociological and educational, indispensable to think critically about the power of social reintegration and our role in society.

This would cause the distressed-reeducated to analyze his own condition in prison: to analyze his future goal of freedom and reunion with his relatives or to indulge in inner death, indifference, a kind of resignation by detachment from his "self", lethargy. Reading the classics makes all these reflections possible. The distressed-reeducating would analyze the pains of the passage of time, the longing for relatives, the restriction of freedom, the precarious conditions in which it is found, shame and guilt (FUDOLI, 2004).

All these moments are found in classic works of Brazilian and universal literature, such as in John Milton's The Lost Paradise, or Machado de Assis's The Alienist. In Milton's work there is the Christian view of human origin, the rebellion and fall of the angels, the creation of Adam and Eve, the temptation by Satan, the expulsion from Paradise and the promise of a future redemption. In The Alienist, the boundaries between what is normal and what is abnormal are discussed through a doctor who tries to understand the psychological disturbances of the population. Excellent works to try to understand the relation between human actions and the established social relations between them (DIP; MORAES JR, 2018).

With all these benefits, reading can still be used as an excellent supplementary educational activity in the remission process.

The reading of classics in literature resocializes the individual. To re-socialize is to rebuild the losses (CNM, 2017, p.11). To socialize is to promote the inclusive return of the afflicted to society. When speaking of inclusive, it is meant that the grieving must be re-educated by the State to acquire its full development citizen to confront the labor market.

\section{FINAL CONSIDERATIONS}

Brazil lacks inclusive public penitentiary and criminal policies in order to escape from the traditional and inefficient repressive and punitive public policy to which it is accustomed. Reading enters as a complementary educational activity, although this opportunity is not yet widely secured, since penitentiaries are rarely used effectively. In this proposal, we advocate the encouragement of reading literature classics, specifically, as a complementary educational 
activity, due to its wide and already known benefit that it generates to the human person. With the grieving-learners, this would be no different.

The possibility of reading classics from the literature in the penal establishment escapes the whole individualizing and repressive framework of crime and violence. It is a form of contact with the outside world in order to express universal situations inherent to life in society. This, therefore, confers on the sufferers the experience of a certain degree of freedom. This is assumed by subsection XV of art. 41 of the LEP, when he states that it is the prisoner's right to contact the outside world through written correspondence, reading and other means of information that do not compromise morality and good manners.

The promotion of inclusive penitentiary and criminal public policies that privilege remission by reading classics from literature fully serves the desire for freedom of the grievingreeducated. The stories of these works are universalizing, which means to say that they reach all times, societies and places, as seen previously. It is a reading that moves the thinking about the ethical, moral and social values of society, because the classics opportunize this reflection through their scenes of universal character. This is important for prisoners to realize because these values are being forgotten and lost over time. And it is this whole framework of benefits that includes being grieved-re-educating back into the world in society.

\section{REFERENCES}

BRAZIL. Plateau. Law 7, 210, 11-7-1984. Available at: <www.planalto.org.br >. Accessed on: 20 Jan. 2019.

BRAZIL. ______. Law 12. 433, of 29-6-2011. Available at: <www.planalto.org.br>. Accessed on: 20 Jan. 2019.

BRAZIL. Law 12. 714, of 14-9-2012. Available at: <www.planalto.org.br>. Accessed on: 20 Jan. 2019.

BRAZIL. MPPR. Criminal Execution Booklet. Available at: <www.mppr.org.br >. Accessed on: 20 Jan. 2019.

BRAZIL. TJDFT. Decision: approval of the list of works of the project remission by reading. Available at: www.tjdft.jus.br. Accessed on: 15 Feb. 2019.

CALVINO, Italo. Why Read Classics? São Paulo: Companhia de Bolso, 2007).

CNM. National Confederation of Municipalities. Social Reinsertion: the right to start over. Brasília: CNM, 2017. Available at: www.cnm.org.br. Accessed on Jan 18. 2019.

CNJ. National Bank for Prison Monitoring. Available at: <www.cnj.jus.br $>$. Accessed on: 18 Jan. 2019.

Postulates, Principles and Guidelines for Criminal Alternatives Policy. Available at: www.cnj.jus.br. Accessed on: 18 Jan. 2019. 
Criminal recidivism in Brazil. 2015. Available at: <www.cnj.jus.br>. Accessed on: 27 feb. 2019 .

Recommendation No. 44 of 11/26/2013. Available at: <www.cnj.jus.br $>$. Accessed on: 20 Mar. 2019.

CNPCP. National Plan for Criminal and Penitentiary Policy. Available at: <www.tjrj.jus. br>. Accessed on: 10 Jan. 2019.

DEPEN. National Survey of Penitentiary Information - 2016. Available at: <www. emporiododireito.com.br>. Accessed on: 10 Jan. 2019.

DIP, Ricardo; MORAES JR., Volney Correa Milk of. Crime and Punishment: politically incorrect reflections. São Paulo: Lepanto, 2018.

ESFFAM, André. Criminal Law: general part. São Paulo: Saraiva, 2017.

Freyre, Gilberto. Casa Grande \& Senzala. São Paulo: Global, 2006.

FUDOLI, Rodrigo de Abreu. Of the Remission of the Privative Penalty of Freedom. São Paulo: Del Rey SP, 2004.

FURTADO, Celso. Economic Formation of Brazil. São Paulo: Companhia das Letras, 2018.

G1. TV Rondônia 4o years: station remembers rebellion in the White Bear. Available at: $<$ http://g1.globo.com/ro/rondonia/noticia/2014/o9/tv-rondonia-4o-anos-emissora-relembrarebeliao-no-urso-branco.html>. Accessed on: o5 feb. 2019.

MALIN, Mauro. Debate seeks roots in violence. Available at: <https://www.acessa.com/ gramsci/?page=visualizar\&id=703>. Accessed on: Dec 20. 2018.

UN. Declaration of the Millennium. Available at: <www.nacoesunidas.org.br $>$. Access in: Jan. 132019.

PERELMAN, Chaïm, OLBRECHTS-TYTECA, Lucie. Treaty of argument. São Paulo: Martins Fontes, 1996.

ROCHA, Ruth. Universal Declaration of Human Rights. São Paulo: Salamandra, 2014.

SACHS, Jeffrey D. The Age of Sustainable Development. Portugal: Current, 2017.

SARLET, Ingo Wolfgang. Dignity of the Human Person and Fundamental Rights in the Constitution of 1988. 7. ed. Rev. E current. - Porto Alegre: Bookstore of the Lawyer, 2009.

SPOSATO, Karyna Batista; MARQUES, Verônica Teixeira (Orgs.). Human Rights and Penitentiary Policy. Maceió: EDUFAL, 2012.

USP. Declaration on the Right to Development. Available at: <www.direitoshumanos.usp.br>. Accessed on: 04 Jan. 2019. 